\title{
Specifics of the Mosaic Reflection Method of Elements of Ethnic Culture
}

Yuri A. Kuzmin

FSBEI of HE "I.N. Ulianov Chuvash State University",

Cheboksary, Russian Federation.

(iD https://orcid.org/0000-0003-4115-9811, e-mail: kya70@mail.ru

Abstract: The article reveals the specifics of the methodology for studying ethnic elements of culture. The nomological paradigm of reflection of the socio-humanitarian sphere constituted the scientific status of ethno-cultural knowledge, at the same time leveling the subjective aspects, created a unification of forms and content, which inevitably led to a distortion of its actual parameters. As a tool for overcoming the imperfection of the classical principles of reflecting the phenomena of ethnic culture, they proposed a method of mosaic reconstruction that allows us to identify the relationship between elements of ethnic culture on the basis of common values. Mosaic reconstruction of ethnic culture reveals the logical relationship between its elements, forms of manifestation, and the totality of prerequisites and grounds. In a general sense, the method of mosaic reconstructions involves the following procedures, such as fixing specific ethnic elements of culture, creating a complex of links of ethnocultural integrity, determining the principles of interaction of system elements with the external and internal environment, applying the mechanism for restoring cultural integrity based on the principles of a cultural research program, visualizing a holistic image ethnic culture. The methodology of mosaic reconstruction is based on the fact that culture is the product of a social form of existence that expresses itself in the corresponding spheres of social activity, the restoration of which in its entirety is a necessary condition for creating an exhaustive image of culture. The author comes to the conclusion that mosaic reconstruction of ethnic culture reveals the logical relationship between its elements, forms of manifestation, and the totality of prerequisites and grounds.

Keywords: cognition, methodology, mosaic reconstruction method, ethnic culture, theory of cognition.

For citation: Kuzmin I.A. (2020). Specifics of the Mosaic Reflection Method of Elements of Ethnic Culture. Etnicheskaya kultura = Ethnic Culture, 4(5), 17-19. DOI:10.31483/r-74998.

Кузьмин Ю.А.

ФГБОУ ВО «Чувашский государственный университет имени И.Н. Ульянова», Чебоксары, Российская Федерация. https://orcid.org/0000-0003-4115-9811, e-mail: kya70@mail.ru

\section{Специфика мозаичного метода отражения элементов этнической культуры}

Резюме: Статья раскрывает специфику методологии исследования этнических элементов культуры. Номологическая парадигма отражения социогуманитарной сферы конституировала научный статус этнокультурного знания, одновременно нивелируя субъективные аспекты, породила унификацию форм и содержания, что неизбежно привело к искажению ее действительных параметров. В качестве инструмента преодоления несовершенства классических принципов отражения феноменов этнической культуры нами предложен метод мозаичной реконструкции, позволяющий выявить зависимость между элементами этнической культуры на базе общих ценностей. Мозаичная реконструкция этнической культуры позволяет выявить логическую зависимость между ее элементами, формами проявления, совокупностью предпосылок и оснований. В общем смысле метод мозаичных реконструкций предполагает выполнение следующих процедур, как закрепление специфических этнических элементов культуры, создание комплекса звеньев этнокультурной целостности, определение принципов взаимодействия элементов системы с внешней и внутренней средой, применение механизма восстановления культурной целостности на основе принципов культурной исследовательской программы, визуализация целостного образа этнической культуры. Методология мозаичной реконструкции исходит из того фракта, что культура является продуктом социальной формы существования, выражающей себя в соответствующих сферах общественной деятельности, восстановление которой в целостности является необходимым условием для создания исчерпывающего образа культуры. Автор приходит к выводу, что мозаичная реконструкция этнической культуры позволяет выявить логическую зависимость между ее элементами, фрормами проявления, совокупностью предпосылок и оснований.

Ключевые слова: познание, методология, метод мозаичной реконструкции, этническая культура, теория познания.

Для цитирования: Специфика мозаичного метода отражения элементов этнической культуры // Этническая культура. - 2020. - № 4 (5). - С. 17-19. DOI:10.31483/r-74998.

\section{Introduction}

The situation that developed at the turn of the XX-XIX centuries in Russian social science refuted simplified ideas about ethnic culture as a form of reflection of the values of relict social technologies, forced to revise the usual images of ethnicity and provided new opportunities for implementing methodological approaches to solving issues related to improving the theory and practice of studying ethnic elements of culture. Methodological reflection in the sphere of rational knowledge is due to the fact that «epistemological practice is initially formed on the basis of an established research tradition that has passed the appropriate verification and falsification tests» [7, p. 18].
The nomological paradigm of knowledge, seeking to give the socio-humanitarian sphere in General and ethnocultural knowledge in particular a strictly scientific status, initially focused on the ideals, norms and principles of natural science, defined as the universal basis of scientific reflection. The nomological concept of the development of ethno-cultural phenomena proceeds from the recognition of the objective nature of socio-cultural reflection, which is subject to the criteria and principles of scientific knowledge in General [3, p. 195]. The consequence of reflecting culture in institutions of the nomological approach is the leveling of its subjective aspects, the unification of forms and content, which inevitably leads to distortion of its actual parameters. 
The conceptual program of the methodology of cognition of ethnic culture, defined as sociocentric, is characterized by a critical attitude to the transfer of the ideals of scientific natural science to the knowledge of culture and proceeds from the specifics of the methodological complex of social and humanitarian Sciences. The most important difference between the sociocentric methodology of reflecting ethnic culture is the recognition of the immanent inclusion of the system of social values in the potential resources of knowledge. French social psychologist, culturologist Abraham Mole, one of the first to use the term «mosaic culture», writes: «knowledge is made up of scattered scraps connected by simple, purely random relationships in the time of assimilation, in the consonance or association of ideas. These scraps do not form a structure, but they have a cohesive force that does not have old logical connections and gives the «knowledge screen» a certain density, compactness, no less than that of the «tissue-like» screen of humanitarian education» [4, p. 107]. It follows that the knowledge of culture is focused on the comprehension of axiological meanings, the development of which requires methodological techniques that are absent in the baggage of natural Sciences.

\section{Discussion}

The ethno-cultural sphere finds its expression in the content of that part of reality that does not exist «outside of human activity: it is produced and reproduced, one might even say constructed by human activity» [5, p. 585]. Culture appears as an institution that is immanently linked to any type of social activity, which is why it appears as an absolute form of expression of the content side of social technologies. In this sense, ethnic culture is the most profound and natural form of social existence [2, p. 58]. The specificity of cognition of the ethno-cultural sphere is the fact that its content is a segment of reality that is immanently realized through social existence, which, in turn, inevitably raises the problem of correlation of axiological priorities and, as a result, the conjugation of objective and subjective aspects of reflection. The objective component is based on the priorities of the biological properties of ethnicity the recognition of this phenomenon as the original, objective quality. The subjective interpretation of ethnicity proceeds from the fact that the property in question can be consciously constructed within the framework of certain public interests. «The culture of society immanently includes value stereotypes that influence the mechanisms of resolving the epistemological situation, which together form the paradigm of knowledge» [1, p. 97].

At the same time, it is obvious that the stated approaches demonstrate the limited prospects for involving ethnic culture as an object of methodological reflection as an exhaustive whole. «The subject a priori deals only with a set of cultural phenomena that are associated with a set of issues that allow achieving concrete results» $[6, \mathrm{p} .55]$. Thus, the set of traditional methods of mastering ethnic culture in the paradigms of socio-humanitarian methodology as a selfsufficient epistemological subsystem does not demonstrate the necessary degree of effectiveness in achieving the goals of knowledge.

\section{Result}

The problem field of ethnic culture as an object of methodological reflection consists in a purposeful effort to reflect its content in its actual parameters, in all the richness and diversity of its causes, forms of datum, value relations and relationships. The complexity of solving these issues is due to the synthetic nature of ethnic culture, which is expressed in the inseparable unity of the phenomena of economic, political, social and spiritual spheres of public life. In this perspective, the philosophical level of ethno-cultural reflection becomes relevant, since the sphere of being of philosophy is directly related to the field of concepts, theoretical generalizations, principles, categories, images.

The essence of ethnic culture as a phenomenon, initially permeated with deep meanings of being, can be mastered in the context of its definition as a «semantic reality», which manifests itself through a system of cultural artifacts that realize their existence as material phenomena. Expressing its definiteness in the system of semantic reality, ethnic culture can be involved in the complex of cognitive reflection through the methodology of metaphysical perception and the potential for integral development of the object in all the richness of its connections and relationships. This circumstance implies the implementation of an approach that reflects the multi-aspect manifestations of ethnic culture while simultaneously demonstrating the unity of the axiological platform and the integrity of the properties of the phenomenon under consideration. As such a tool, it is interesting to include the mosaic reconstruction method in the research paradigm of ethnic culture analysis.

\section{Conclusions}

The mosaic method is a specific technology for creating an image by attaching a certain fragment to a common base that binds the structure, while each fragment is located in its own strictly defined place, ensuring the necessary integrity. Reconstruction is a prerequisite for epistemological reflection, since it allows us to restore the system of interaction of elements of ethnic culture and is implemented in the unity of forms of sensory and rational reflection with the dominant status of the latter. Rationality correlates the results obtained and, through establishing relationships between them, discovers new things. Reconstruction is based on the reproduction of forms, connections, relationships, stages of the emergence of cultural phenomena as systemic entities. In itself, the reconstruction of phenomena cannot be considered as an independent methodology of cognition, since the restoration system can include elements not only of ethnic culture, but also divisions of ethnic culture that are not included in the genotype of existential technologies of the social organism. The method of reconstruction allows us to restore images of culture in the context of axiological meanings of being an ethnic community.

The essence of the method of mosaic reconstructions is to fix the various forms of manifestation of cultural principles as ideal images and, linking them with each other, to construct a unified picture of the ethno-cultural space. Mosaic reconstruction of the properties of ethnic 
culture ensures its existence as a transcendental one, which provides an opportunity for creative interpretation of its meanings, thereby helping to overcome the limitations of methodological resources of highly specialized disciplines. The method of mosaic reconstructions provides resources for determining the essential regularities of the organization of ethnic culture as a complex of interacting axiological priorities expressed in various spheres of life of the socio-cultural community. We assume the method of mosaic reconstruction as a complex synthesis of reflexive institutions that act as a tool for cognizing an object in the internal and external manifestations of its stages of formation and development.

In a very General sense the method of mosaic reconstructions involves the implementation of the following procedures:

a) fixing the elements of culture that make up its ethnic specificity;

b) establishing a complex of links of ethno-cultural integrity;

c) defining the principles of interaction of system elements with external and internal environments; d) application of the mechanism of restoration of cultural integrity based on the principles of the cultivated research program.

e) visualization of a complete image of ethnic culture.

The method of mosaic reconstruction can be implemented in the case when there are various forms of manifestation of a single basis; restoring the order of connections between cultural objects will allow determining the integrity of the cultural system in any complexity and quantitative multiplicity of phenomena that make up it. The implementation of the mosaic reconstruction method is associated not so much with the definition of cultural phenomena as with the establishment of their place and role in the existence and functioning of ethnic culture.

Thus, the methodology of mosaic reconstruction proceeds from the fact that culture is the product of a social form of existence that expresses itself in the corresponding spheres of social activity, the restoration of which in its entirety is a necessary condition for creating an exhaustive image of culture. Mosaic reconstruction of ethnic culture reveals the logical relationship between its elements, forms of manifestation, a set of prerequisites and bases.

\section{References}

1. Bakaeva Zh. Yu., Stepanov A. G., Matveeva O. L. Constants of utopian as the basis of the mythological picture of socio-historical reality // Manuscript. - 2019. - Vol. 12. - №6. - P. 95-98.

2. Zemlyanova L.M. Contemporary American Communication Studies: Theoretical Concepts, Problems, Forecasts. - M.: Moscow State University, 1995. - $271 \mathrm{p}$.

3. Kara-Murza S.G. Manipulation of consciousness. Century XXI. - M.: Algorithm, 2015. -464 p.

4. Mole A. Sociodynamics of culture. - M.: Progress, 1973. - 406 p.

5. Mukin V. A., Sokolova L. Yu. Spiritual orientations of a person in the conditions of knowledge economy // Accounting, analysis and audit in the conditions of digital economy materials of the all-Russian scientific and practical conference. - 2018. - P. 580-587.

6. Stepanov A. G. Specificity of the rational-analytical level of formation of the picture of socio-historical reality // Bulletin of the Omsk state pedagogical University. Humanitarian research. - 2019. - №3 (24). - P. 53-56.

7. Stepanov A. G. The theory of reverse projection of Professor E. Z. Feizov in solving the problem of the main question of philosophy. Collection of scientific articles of the Department of philosophy, sociology and pedagogy. Executive editor I. E. Poverinov. -2019. - P. 14-19.

\section{Список литературы}

1. Бакаева Ж.Ю. Константы утопического как основания мифологемы картины социально-исторической реальности / Ж.Ю. Бакаева, А.Г. Степанов, О.Л. Матвеева // Манускрипт. - 2019. - Т. 12, №6. - С. 95-98.

2. Землянова Л.М. Современная американская коммуникативистика: теоретические концепции, проблемы, прогнозы / Л.М. Землянова. - М.: МГУ, 1995. - 271 с.

3. Кара-Мурза С.Г. Манипуляция сознанием. Век ХХІ / С.Г. Кара-Мурза. - М.: Алгоритм, 2015. - 464 с.

4. Моль А. Социодинамика культуры / А. Моль. - М.: Прогресс, 1973. -406 с.

5. Мукин В.А. Духовные ориентиры человека в условиях экономики знаний / В.А. Мукин, Л.Ю. Соколова // Учет, анализ и аудит в условиях цифровой экономики: материалы Всероссийской научно-практической конференции. - 2018. - С. $580-587$.

6. Степанов А.Г. Специфика рационально-аналитического уровня становления картины социально-исторической реальности / А.Г. Степанов // Вестник Омского государственного педагогического университета. Серия: Гуманитарные исследования. - 2019. №3 (24). - С. 53-56.

7. Степанов А.Г. Теория обратной проекции профессора Э.З. Феизова в решении проблемы основного вопроса философии / А.Г. Степанов // Феизовские чтения: сборник научных статей кафедры философии, социологии и педагогики / отв. ред. И.Е. Поверинов. $-2019 .-$ С. $14-19$.

\section{Information about the author}

Yuri A. Kuzmin - senior lecturer of the Department of Department of Criminal Sciences, FSBEI of HE

"I.N. Ulianov Chuvash State University", Cheboksary, Russian Federation.

\section{Информация об авторе}

Кузьмин Юрий Анатольевич - старший преподаватель кафедры уголовно-правовых дисциплин ФГБОУ ВО «Чувашский государственный университет имени И.Н. Ульянова», Чебоксары, Российская Федерация. 